\title{
As representações do intelectual no manifesto Mais uma vez convocados (1959)
}

The representations of the intellectual at "Mais uma vez convocados" manifest (1959)

Sérgio de Sousa Montalvão

Doutor em História Professor Adjunto II da Universidade Federal Fluminense stalvao@yahoo.com.br

Resumo: O artigo trata das representações do intelectual no manifesto Mais uma vez convocados, publicado no contexto de tramitação da primeira Lei de Diretrizes e Bases (LDB) no Congresso Nacional. Na leitura do documento, divulgado em julho de 1959, foram destacadas as representações do "compromisso com a verdade" e do "dever de exposição pública" dos intelectuais da educação. Em sequência, foram discutidas as afinidades do manifesto com a opinião do jornal $O$ Estado de S. Paulo, típicas de um tempo em que os liberais ainda acreditavam em reformas dentro da legalidade.

Palavras Chaves: Lei de Diretrizes e Bases (LDB), Manifesto dos Educadores, Fernando de Azevedo, O Estado de S. Paulo.

\begin{abstract}
The article deals with the representations of the intellectual in the "Mais uma vez convocados" manifest, published during the proceedings of the first Lei de Diretrizes e Bases (Guidelines and Bases Act) in the Brazilian Congress. In reading the document, released in July 1959, we have highlighted the representations of "commitment to the truth" and of "public exposure duty" of the intellectuals in Education. In sequence, we discuss the manifest affinities with the opinion of the newspaper $O$ Estado de $S$. Paulo, that were typical of a time when liberals still believed in reforms within the law.
\end{abstract}

Keywords: Guidelines and Bases Act, Manifest of the Educators, Fernando de Azevedo, O Estado de S. Paulo. 
O manifesto dos educadores de junho de 1959 foi a maior resposta da intelectualidade liberal-democrática ao movimento da Igreja Católica, e dos proprietários de escolas particulares, pela revisão do projeto de Lei das Diretrizes e Bases da Educação Nacional (LDB), que culminou na apresentação dos substitutivos do deputado Carlos Lacerda ao projeto $\mathrm{n}^{\circ}$. 2.222/57, até então, a síntese das proposições sobre o tema.

Depois de quase uma década de paralisia congressual, a lei complementar da Constituição de 1946 começava a avançar, em parte devido ao encaminhamento dado pelo ministro Clóvis Salgado. A iniciativa do Poder Executivo buscava uma fórmula conciliadora que levasse a LDB à votação em plenário, sem desfigurar a estrutura original proposta pela Comissão Mariani em 1948. ${ }^{1}$ Nas palavras do titular do Ministério da Educação e Cultura (MEC) durante do governo Juscelino Kubitschek, em depoimento recente:

O substitutivo foi bem aceito e ia ser aprovado em 1958. Ele chegou em segunda discussão ao plenário para ser aprovado. Mas nesse momento, Carlos Lacerda se levantou contra o projeto, alegando razões de ordem geral na parte doutrinária da lei e sobretudo na questão do ensino particular e do ensino público. A lei tinha tendências de maior inclinação para o serviço público, enquanto Carlos Lacerda defendia uma orientação que era da Igreja, de que o ensino devia ser particular. Quer dizer, democraticamente, a educação só se poderia realizar através dos particulares e não através do poder público, que teria uma tendência a colocar a administração a seus serviços etc. O que se pretendia era o sistema da Holanda, em que o governo dá dinheiro para as escolas particulares realizarem o ensino, inclusive gratuito, para toda a população (MONTEIRO, 2007: 148).

O ano de 1958 ficou conhecido pela campanha dos representantes católicos em defesa da liberdade de ensino. Eles a dirigiram contra o que consideravam o impedimento imposto pelo Estado, sobretudo às classes populares, das famílias escolherem o gênero de educação dos seus filhos. A solução do problema estaria no redirecionamento da verba

\footnotetext{
${ }^{1}$ Comissão organizada pelo ministro Clementi Mariani (da Educação e Saúde Pública, no governo Eurico Dutra) para apresentar o anteprojeto da LDB como proposta do Poder Executivo ao Congresso Nacional. A comissão de quinze membros teve como presidente Lourenço Filho e relator Antônio Almeida Júnior. O documento final chegou em abril de 1948 na Câmara dos Deputados, onde permaneceria arquivado durante anos.
} 
pública para o setor privado, naquele momento formado majoritariamente por instituições confessionais católicas. Essa inversão permitiria o oferecimento de mais escolas de acordo com os anseios da maioria da população, não disposta a receber uma educação laica, impregnada da visão cientificista do mundo.

O discurso católico repercutiu nos aparelhos de comunicação mantidos pelas diversas ordens religiosas. Nessa conjuntura, intelectuais identificados ao catolicismo militante também assinaram artigos em jornais de grande circulação. No entanto, o principal agente favorável às reivindicações descritas no parágrafo anterior foi a Associação da Educação Católica (AEC). Fundada no término do Estado Novo (19371945), a entidade unia esse segmento das instituições particulares de ensino em torno da difusão de uma ideologia contrária à interferência estatal nos assuntos considerados próprios à organização escolar (SENRA, 2011: 110).

Um dos pleitos mais significativos da AEC referia-se à desregulamentação do reajuste das mensalidades escolares, determinado pela Comissão Federal de Abastecimento e Preços (COFAP). Em face à decisão desse órgão administrativo de não reajustar para o ano seguinte os valores cobrados em 1957, a AEC manifestou o seu descontentamento através de um telegrama enviado ao presidente da República, depois publicado na revista Servir, criticando a medida que "sem estudo prévio e consciencioso da realidade nacional, feriu profundamente os diretores, mestres e funcionários das escolas particulares" (A AEC condena..., 1958: 19-23).

Indispostos com os rumos da $\mathrm{LDB}$, os setores católicos obtiveram um instrumento de luta parlamentar, em finais de 1958, quando Lacerda levou a campanha pela liberdade de ensino para a tribuna da Câmara Federal e a comissão legislativa pertinente. Além de discordar do controle burocrático da educação, o deputado udenista atendia às demandas privatistas, procurando estabelecer um freio à expansão da escola pública-estatal. ${ }^{2}$ Considerando essa expansão como parte de um movimento que redundaria no regime de "escola única" controlada pelo Estado, o discurso lacerdista se desenvolveu em um campo semântico que opunha liberdade de ensino e totalitarismo (MONTALVÃO, 2013).

\footnotetext{
${ }^{2} \mathrm{O}$ objetivo de sustar a expansão do ensino público, configurando uma ação supletiva do Estado nos assuntos da educação, fica evidente no artigo $10^{\circ}$ do Título IV (O Estado em relação ao ensino), do substitutivo apresentado à Comissão de Educação e Cultura da Câmara dos Deputados (CECCD), em dezembro de 1958: "Competem ao Estado as seguintes funções: 1) dar, quando solicitado, assistência técnica e material às escolas, a fim de lhes assegurar, em benefício da comunidade, o mais extenso e intenso rendimento de trabalho; 2) fundar e manter, em caráter supletivo, escolas oficiais, quando e onde o ensino não puder atender plenamente à população escolar" (ATA, 1958: 7.623). Como nesse momento Carlos Lacerda não fazia parte da CECCD, o substitutivo foi apresentado pelo deputado udenista cearense Antônio Perilo de Sousa Teixeira.
} 
Para os apoiadores de Mais uma vez convocados, a principal motivação do manifesto era restaurar a verdade no espaço público. A luta pela liberdade de ensino não poderia continuar sendo vista como um combate aos perigos do monopólio estatal. Voltar à cena e dizer que os substitutivos de Carlos Lacerda patrocinavam o interesse das instituições privadas tornava-se uma obrigação daqueles que, desde a divulgação do Manifesto dos pioneiros da educação nova (1932), lutavam pela modernidade educacional no Brasil.

$\mathrm{O}$ artigo em tela irá tratar das representações do intelectual no Manifesto dos educadores: Mais uma vez convocados, ressaltando o compromisso com a verdade e o dever de exposição pública.

A verdade referida estava em mostrar que a consolidação do ensino público, através do marco legal da LDB, não intencionava anular ou dificultar a liberdade de ensino dos particulares, nem contrariar a orientação religiosa das famílias; mas ampliar a oferta de oportunidades escolares, considerada representativa do tempo de maior participação dos indivíduos nas comunidades nacionais. Diante das críticas desfechadas pelos representantes do ensino privado, anteriormente resumidas, os manifestantes de 1959 pregaram a necessidade do contraditório, nele incluída a justa exposição do que estaria acontecendo. $\mathrm{O}$ passo de entrada do intelectual no espaço público não coincidia, portanto, com a expressão de um determinado pensamento ou ideologia política, devendo-se a uma convocação imaginária para expor a verdade dos fatos, manipulada pelos adversários em nome dos seus próprios interesses.

No entanto, embora a luta dos defensores da escola pública, em um primeiro momento, se mostrasse pelo combate às calúnias intensamente repetidas, impedindo-as de se cristalizarem enquanto verdades, a divulgação do manifesto representou uma quebra de silêncio coletiva, oportuna para a mostrar, como dissera Anísio Teixeira, "a educação que nos convém":

A escola é hoje, deve ser, sem dúvida, um processo de redistribuição dos indivíduos, segundo suas aptidões, pelos diferentes escalões do trabalho moderno; mas não há nenhuma escola, e muito menos nenhuma escola uniforme e única, pela qual se possa passar de uma "classe" para outra. O próprio conceito de escola de "classe" desapareceu para se passar a considerar todo o sistema escolar como um sistema contínuo, pelo qual todos se educam até o nível primário, e daí por seleção de capacidades e aptidões, alguns ou 
muitos prosseguem no nível médio ou superior, em escolas tão variadas e flexíveis quanto possível, para atender a variedade de aptidões dos candidatos à educação, sem distinção de classe nem situação econômica (TEIXEIRA, 2005 [1957]: 210).

Essas promessas da educação democrática em sociedades abertas ao talento já consistiam em uma opinião jornalística na cidade que primeiro recepcionou Mais uma vez convocados. O jornal O Estado de S. Paulo manteve, no decorrer dos debates parlamentares, uma linha editorial contrária aos substitutivos de Carlos Lacerda. O posicionamento do jornal, lembrado repetidas vezes no manifesto, como será visto adiante, alerta-nos para as afinidades entre este órgão da imprensa paulista e o pensamento político-pedagógico que orientou o documento de julho de 1959

\section{Os intelectuais da educação e o compromisso com a verdade}

Coube a Fernando de Azevedo redigir o Manifesto dos educadores. O texto do antigo reformador escolar dos anos 1920 e 1930, renomado e polêmico líder do escolanovismo no Brasil, foi construído para criar a imagem do intelectual que não suja as mãos no jogo político. A entrada em cena dos manifestantes que o apoiaram, portanto, não poderia ter sido motivada por disputas representativas de qualquer partido, setor ou classe social. Tratava-se de uma contenda envolvendo modernidade e arcaísmo, interesse público e interesse privado, responsabilidade e irresponsabilidade perante os assuntos da educação.

A forma redacional de Mais uma vez convocados é um indício da cultura intelectual que o circundava, ou seja, do engajamento cívico dos homens e mulheres de letras em causas abrangentes e capazes de servir à proteção da sociedade. O estudo da correspondência entre os principais articuladores do manifesto, feito na tese de João do Prado Ferraz de Carvalho, evidenciou que essa postura também foi tomada para evitar que o documento “fosse ‘carimbado' como sectário”, conforme expressão utilizada por Fernando de Azevedo em uma das cartas endereçadas a Paschoal Lemme (CARVALHO, 2003: 71). Decerto que os participantes do manifesto eram pessoas envolvidas, em grande parte, direta e profissionalmente, com a causa defendida, podendo ser percebidos como um agrupamento intelectual devido à feição de criadores e mediadores de um determinado aparato técnico, científico e cultural. O redator do documento, naquele momento, ocupava 
a direção do Centro Regional de Pesquisas Educacionais de São Paulo (CRPE-SP), dependência administrativa subordinada ao Instituto Nacional de Estudos Pedagógicos (INEP). Contudo, na conjuntura política em questão, os postulantes do manifesto se apresentavam como ativistas lutando a partir de uma tomada de consciência individual, autônoma e independente dos seus papéis profissionais. ${ }^{3}$

Os intelectuais da educação - reunindo um número expressivo de cento e noventa assinaturas - procuravam dar vida à causa da escola pública, após a expectativa de empreender uma ampla reforma educativa, em nível nacional, tendo como ponto de partida a LDB, ver-se desgastada pela longa tramitação do projeto e a reviravolta provocada pelos substitutivos de Carlos Lacerda. ${ }^{4} \mathrm{Na}$ correspondência de Paschoal Lemme para Fernando de Azevedo, aquele que segundo a tese de Carvalho seria o mais insistente defensor de uma nova declaração coletiva via o projeto de reconstrução educacional estacionado, devido aos labirintos da história política, exigindo um ato capaz de rearticular os educadores mais combativos (2003: 48). Na tentativa de reverter a incômoda situação presente, o objetivo do grupo que urdiu o manifesto era usar o prestígio acumulado ao longo do tempo para falar a "verdade ao poder". ${ }^{5} \mathrm{O}$ compromisso com a verdade é a representação mais enfática do intelectual em Mais uma vez convocados, logo encontrada nas suas primeiras linhas:

\footnotetext{
${ }^{3}$ Utilizo aqui a conhecida abordagem de Jean-François Sirinelli sobre o "caráter polissêmico da noção de intelectual", que permite uma definição mais abrangente (socioeconômica e profissional) e outra mais restrita (política e conjuntural) a esse respeito. Deve-se acrescentar a essa dupla acepção, a importância conferida por esse historiador aos meios em que circulam as ideias: revistas, jornais e manifestos. Os impressos, para Sirinelli, revelam "espaços de sociabilidade" que estruturam o campo intelectual, mediando a formação de grupos cooperativos ou rivais (SIRINELLI, 1996: 234-236).

${ }^{4}$ Questionado se a LDB seria a solução mais adequada aos problemas da educação nacional, Anísio Teixeira respondeu à revista $O$ Cruzeiro, em 23 de abril 1959: "Não é a solução nem de todos nem de nenhum problema do ensino. Será um início de marcha. Andamos emaranhados em um agitado e estéril círculo vicioso. Como não acreditávamos no país, armamos-lhes uma camisa de força de exigências a-priorísticas para que pudesse ele abrir e manter escolas. Como tais exigências a-priori de requisitos perfeitos e uniformes para o ensino não são realizáveis e a nação entrou a exigir educação como sua imposição suprema - passamos a facilitar o cumprimento das exigências e a dar aos resultados do ensino um valor formal e, deste modo, expandimos fraudulentamente o sistema. A lei de diretrizes e bases se for o que me parece que deve ser libertar-nos-á desse impasse. Permitirá, facultará que a educação se organize segundo as nossas forças, e fixará a-priori os seus padrões, melhorando-os ano a ano, a luz dos resultados do ensino e não das condições formais em que, aparentemente, ele foi ministrado" (TEIXEIRA apud MONTALVÃO, 2011: 7 , epígrafe). A reposta do então diretor do INEP serve de indicativo das expectativas causadas pela lei entre os educadores liberais.

${ }^{5}$ Refiro-me a expressão encontrada no livro de Edward Said, Representações do intelectual (2005), em que o crítico literário afirma que os intelectuais são figuras representativas, que se colocam diante do público ele diz que não existem intelectuais privados - falando, escrevendo ou aparecendo nos meios audiovisuais. Os intelectuais têm o poder de representar ideias, dando forma, expressão e visibilidade a conceitos e abstrações que se perderiam sem a sua presença catalizadora.
} 
Se nem todo o momento será julgado oportuno para dizer a verdade, sobretudo se amarga e dura, não se poderá esperar ocasião para restabelecê-la, que é dever de todos, quando desfigurada, proclamá-la sem rebuços e meias palavras. Mas também sem veemência e brutalidade, que desses recursos homens de espírito não seriam capazes de utilizar-se nem necessitam as verdades para serem sentidas ou restauradas na plenitude de sua força (MANIFESTO, 2003 [1959]: 157).

E ainda mais intensamente, a seguir:

A verdade impõe-nos a consciência dizê-la inteira, com sinceridade radical, serena energia e ardor lúcido, sem trazer, porém, o debate a que fomos convocados, a terreno inconveniente, sem lhe imprimir o caráter polêmico, de antagonismos pessoais, a que, em circunstância alguma, deveriam descer, como infelizmente já desceram, as discussões em matéria de tamanha magnitude (Idem: 157).

A "sinceridade radical” é o predicado que melhor justifica a convocação para estar no grupo de 1959. Diante das acusações que lhe foram impetradas, os organizadores do manifesto não entendiam a defesa da escola pública como uma disputa interpretativa, em torno de opiniões contrárias, mas como uma luta pela restauração da verdade dos fatos, sem a qual seria impossível qualquer debate razoável. Haveria uma enfática e mal dissimulada campanha contra a escola pública, resumida na proposta de reposicionar o Estado em uma função supletiva na oferta de vagas escolares. Proclamar a verdade - "sem rebuços e meias palavras" - tornava-se necessário diante da mentira deliberada produzida durante a campanha pela Liberdade de Ensino, cujo extremo seria uma alegada postura totalitária embutida na expansão do ensino público.

O ensaio de Hannah Arendt (1988) intitulado Verdade e política tratou das relações entre verdade fatual e opinião, podendo orientar algumas de nossas reflexões. A verdade, racional ou fatual, segundo Arendt, carrega um elemento coercitivo fazendo-a não ter boas relações com a política. A verdade, seja ela qual for, precisa ser reconhecida, no que proscreve o debate político. ${ }^{6}$ Por esse ângulo, pode-se dizer que Mais uma vez

\footnotetext{
${ }^{6}$ Hannah Arendt (1998) não deixou despercebido que, na História da Filosofia Ocidental, a relação entre a busca pela verdade e o poder político foi estremecida desde a condenação e morte de Sócrates, geradora de uma reação movida por Platão, na tentativa de tornar a filosofia algo decisivo para os destinos da polis.
} 
convocados procurou interditar o debate escola pública versus particular, considerandoo esgotado no momento em que os seus opositores deixaram de respeitar as barreiras éticas da veracidade das argumentações. Essa interdição, no entanto, não teria o propósito de eliminar a política do espaço público, mas reconfigurá-la como dever moral.

Os participantes do manifesto escrito por Fernando de Azevedo retomavam o tipo de ação que caracterizou os intelectuais desde o "caso Dreyfus", contra a mentira generalizada e o erro judiciário, assumindo o papel de acusadores (RODRIGUES, 2005).

\section{Os intelectuais da educação e o dever da exposição pública}

O termo "intelectual" se consolidou nos primeiros anos do século XX para adjetivar um conjunto heterogêneo de produtores de bens culturais e científicos que julgavam sua a responsabilidade de interferir no espaço público, utilizando a comunicação verbal, a fim de tratar de questões éticas que repercutiam na condução política da sociedade (BAUMAN, 2010). Essa representação do intelectual foi atualizada em Mais uma vez convocados:

É, pois, num estado de espírito, limpo de paixões e de interesses, que lançamos esse novo Manifesto ao povo e ao governo. Os que porventura pensam ou pensarem de maneira diferente, hão de reconhecer-nos, por amor ao princípio de liberdade, que são os primeiros a invocar, o direito que nos assiste e temos, antes por um dever indeclinável, de apresentar e submeter ao julgamento público os nossos pontos de vista sobre problemas da gravidade e complexidade com que se apresentam os da educação (MANIFESTO, 2003 [1959]: 157).

A representação do intelectual movido pelo "dever indeclinável" de expor publicamente seus pontos de vista complementa a anterior, do compromisso com a verdade. Se a luta pela reconstrução educacional do Brasil dependia da capacidade comunicativa emanada de uma "sinceridade radical", do mesmo modo, dizia o manifesto, era preciso "um estado de espírito, limpo de paixões e interesses" para expor a verdade. Essa condição da alma auxiliaria a dizer o necessário com "serena energia e amor lúcido",

Contemporaneamente, a posição dos intelectuais na condução das sociedades dependeu muito das formas de institucionalização do saber-poder. 
excluída a "brutalidade" e os "antagonismos pessoais", recursos dispensáveis aos participantes da empreitada.

A leitura do Manifesto dos educadores indica também que o "esforço para a reconstituição dos fatos" impeliu seus participantes a sobreporem "os fantasmas do medo e da ameaça que vagueiam nessa cerração, feita de confusões intencionais ou inconscientes" (MANIFESTO, 2003 [1959]: 157). O engajamento intelectual teria por finalidade atingir objetivos considerados benéficos às maiorias sociais: a integração social pela escola e a conquista, da parte dos alunos, de uma atitude autônoma perante o mundo moderno. Nesse sentido, a análise de Helena Bomeny sobre a trajetória dos pioneiros da educação nova, ao enquadrá-los dentro de uma experiência referida como religião cívica pela democracia no Brasil (2001) (retomando a expressão de Richard Rorty, no estudo sobre o pragmatismo norte-americano), deixa uma sugestão a ser aproveitada.

A socióloga lembra a trajetória de Fernando Azevedo como símbolo da "aposta no progresso social pela educação" (BOMENY, 2001: 159), ou seja, a sua presença catalizadora enquanto ocupante de posições-chave na administração pública coincidindo com a exposição pública do intelectual. O mesmo valeria dizer em relação a Anísio Teixeira, principal alvo dos ataques da Igreja Católica desde que assumiu a direção do INEP no governo JK. A continuidade de ambos nas posições ocupadas dependeu, entre outros elementos, da capacidade de persuadir o público com suas ideias, mesmo quando estas provocavam embaraço e iam de encontro às visões de mundo estabelecidas.

O entusiasmo pela educação nova, essa "religião cívica", geradora de um potencial carisma, entretanto, só poderia causar algum efeito transformador caso assistida pela sequência das políticas públicas. Atingir as novas gerações de educadores era imprescindível nesse processo. Essa conquista dependia daquilo que Norberto Bobbio chamou "princípios-guia" e "conhecimentos-meio" (1997: 73-74). ${ }^{7}$ A "religião cívica pela democracia" oferecia a educação progressiva como princípio de ação. Os meios para efetivação dessa proposta estavam no Manifesto dos pioneiros (1932), que recomendava uma doutrina federativa e descentralizadora. Esta doutrina de fundo liberal, segundo o

\footnotetext{
${ }^{7}$ Estudando as dúvidas e opções dos homens de cultura, o filósofo Norberto Bobbio escreveu que se pode definir o intelectual como o ideólogo que "fornece princípios-guia" e como o experto que "fornece conhecimentos-meio". A partir desses tipos ideais, e baseado na distinção weberiana que divide as ações racionais segundo os valores e segundo os fins, Bobbio afirmou que os ideólogos "elaboram os princípios com base nos quais uma ação é justificada", enquanto os expertos "[indicam] os conhecimentos mais adequados para o alcance de um determinado fim” (1997: 73-74). Os ideólogos seriam movidos pela ética da convicção e os expertos pela ética da responsabilidade. Em nosso caso, acredito que os intelectuais da educação estivessem entre a ética a convicção e a ética da responsabilidade.
} 
manifesto de 1959, teria demarcado a política educacional das Constituições de 1934 e 1946.

No contexto da luta política pela LDB, dar uma resposta à concepção de liberdade de ensino colocada nos substitutivos do deputado Carlos Lacerda foi considerado o dever imediato dos intelectuais reunidos no Manifesto dos educadores:

Quando, porém, o Congresso se dispunha a iniciar a discussão desse projeto de lei que ali passara por um dilatado período de hibernação, desencadeia-se inesperadamente uma ofensiva contra a escola pública, em nome da liberdade de ensino. Não precisamos olhar de perto demais essa estranha concepção de liberdade, defendida em documento público que tem tido ampla divulgação. Receamos muito que ela não suporte bem a análise, em todas as suas implicações econômicas, religiosas e políticas. Todavia, cremos entender bem o que querem dizer; e um manifesto de educadores não poderá esquivar-se a atacar de frente as questões que envolve e é preciso distinguir e destacar, para esclarecer a nossa posição, ainda que nos custe essa sinceridade dissabores e incompreensões (MANIFESTO, 2003 [1959]: 162-163).

O trecho acima mostra que os participantes do manifesto não poderiam "esquivarse" de ir a público esclarecer a sua posição a respeito da liberdade de ensino, pouco importando se isso custasse "dissabores e incompreensões". Agir dessa forma não contribuiria apenas para evitar ameaças diretas ao projeto renovador de escolarização da sociedade. Teria repercussões sobre a imagem daqueles que ocupavam o espaço público para dizer o que era necessário ser dito, apesar de tudo.

\section{Ecos da imprensa paulista}

Destaca-se no grupo dos apoiadores de Mais uma vez convocados um nome que não poderíamos enquadrar como intelectual no sentido de desenvolvedor de ideias ou criações artísticas, nem como liderança acadêmica, mas que cumpria o papel de organizador cultural na cidade de São Paulo, local que primeiro recepcionou o manifesto. Era ele o empresário Júlio de Mesquita Filho, diretor de redação do jornal $O$ Estado de $S$. 
Paulo. Essa publicação antecipou muitos argumentos encontrados no texto de Fernando de Azevedo. ${ }^{8}$

No final da década de 1950, os editoriais sobre educação d’O Estado de S. Paulo eram escritos por um dos participantes de Mais uma vez convocados, Laerte Ramos de Carvalho, professor de História e Filosofia da Educação da Universidade de São Paulo (USP). Eles convergiam com o jornal de Júlio de Mesquita Filho em uma mesma consideração sobre um projeto liberal para o Brasil (BONTEMPI, 2001). O liberalismo do Estadão pregava a importância da educação básica como solução inicial para se atingir as condições mínimas de igualdade entre os cidadãos de uma comunidade nacional. A educação escolar teria um lugar estratégico na conquista de uma civilização integrada e capaz de alcançar paulatinamente o progresso. O jorna desconfiava da política de massas e acreditava na missão da elite intelectual e técnica para conduzir os destinos do país. Neste sentido, o tema da LDB representava um tipo de decisão política em que a racionalidade e o conhecimento especializado deveriam falar mais alto.

Na edição de 7 de janeiro de 1959, o tradicional diário paulistano assim se posicionava contra o primeiro substitutivo de Carlos Lacerda, no editorial "Liberdade de ensino remunerada":

O substitutivo que pretendeu deslocar, na Câmara Federal, o projeto da Comissão de Educação e Cultura sobre Diretrizes e Bases da Educação Nacional, apresenta como linhas mestras de sua estrutura estes três princípios fundamentais: $1^{\circ}$ ) o ensino será ministrado sobretudo pelas entidades privadas e, supletivamente, pelo poder público; $2^{\circ}$ ) o ensino particular não será fiscalizado pelo Estado; $3^{\circ}$ ) o Estado subvencionará as escolas privadas, a fim de que estas possam igualar os vencimentos dos seus professores aos vencimentos dos professores oficiais. É como se vê, a instituição, no Brasil, do reinado do ensino livre: livre da fiscalização do Estado, mas remunerados pelos cofres públicos. Em vez de "pagar para ver", o Estado "pagará sem ver" (O ESTADO DE S. PAULO apud BARROS, 1960: 22).

\footnotetext{
${ }^{8}$ Fundado no século XIX, com o nome de A Província de São Paulo, o jornal da família Mesquita era uma conhecida expressão do liberalismo paulista. No decorrer da sua história, os dirigentes do jornal estiveram diversas vezes envolvidos na causa da educação pública, entendendo-a como alicerce da sociedade liberaldemocrática. $O$ Estado de S. Paulo foi responsável, entre outras ações, pelo inquérito sobre a Instrução Nacional (1926), dirigido pelo próprio Fernando de Azevedo, à época redator do jornal; e pela campanha a favor da criação da Universidade de São Paulo (USP), financiando parte dos gastos com a missão francesa que inaugurou o corpo docente da instituição (CARDOSO, 1982; LIMONGI, 1988).
} 
O Estadão encampou a luta contra o substitutivo de Carlos Lacerda por enxergálo como um surto de irracionalidade política, uma inconveniente defesa da intolerância doutrinária, ameaçadora do espírito liberal. Por outro lado, os intelectuais da educação representavam o bom senso, o discurso científico, metódico, desapaixonado, que poderia beneficiar a todos com decisões mais acertadas sobre as diretrizes e bases. O jornal via o Estado nacional como árbitro capaz de organizar o sistema educacional de modo a produzir igualdade entre os cidadãos.

Na batalha da educação desde a década de 1920, O Estado de S. Paulo ainda carregava o otimismo pedagógico daqueles anos, em que o jornal julgava a reforma escolar um ponto de apoio necessário à emergência de novas camadas dirigentes. $\mathrm{O}$ Estadão vislumbrava na escola republicana, laica e moderna, um importante papel na quebra da mentalidade tradicional, católica e bacharelesca, a ser superada por uma visão de mundo alicerçada na técnica e na ciência (CAPELATO, 1989).

$\mathrm{Na}$ cobertura da tramitação da LDB, além das inúmeras reportagens, o jornal divulgou quarenta e cinco editoriais a esse respeito (CARVALHO, 2003). O emblemático editorial de 7 de janeiro de 1959, mais de uma vez diretamente citado por Fernando de Azevedo no Manifesto dos educadores, demonstra a relevância dessa opinião para abalizar as posições do grupo representado pelo educador. O texto partiu do exemplo italiano do pós-Segunda Guerra Mundial para explicitar a posição do jornal quanto à liberdade de ensino. Naquele país, durante a discussão do projeto constitucional republicano veio à tona a proposta de um ensino livre e subsidiado pela nação, que logo enfrentaria uma onda de protestos. O filósofo Benedetto Croce, um dos líderes do movimento de rejeição ao ensino livre, escreveu que, se aprovado, o projeto representaria a "renúncia às grandes conquistas do século XIX".

O editorialista de $O$ Estado de S. Paulo atribuía à civilização liberal a herança educacional em que o cidadão teria direito a uma rede de escolas primárias que o acolhesse numa "base afetiva e cultural comum" ( $O$ ESTADO DE S. PAULO apud BARROS, 1960: 22). Apesar da liberdade de ensino ter sido aprovada na Itália, esta ficaria limitada por dois artigos da Constituição de 1948:

A mesma Constituição que no art. $7^{\circ}$ adotou o Pacto de Latrão, inscreveu depois, em dois tópicos do art. 33, dispositivos que limitam as prescrições daquele pacto. Um deles assegura às "entidades e aos particulares" o direito de manter escolas e institutos de educação, mas "sem ônus para o Estado". E 
o outro estabelece o exame de Estado para admissão às várias ordens e graus de escolas, para a conclusão dos cursos, e para a habilitação ao exercício profissional (O ESTADO DE S. PAULO apud BARROS, 1960: 23).

O jornal lembrou ainda que a experiência da liberdade de ensino foi ensaiada no Brasil duas vezes, com graves perdas para a educação. Em 1879, a reforma do ministro Leôncio de Carvalho "abusou demagogicamente da expressão "ensino livre" a fím de captar o apoio da mocidade acadêmica, que naquela época constituía uma verdadeira potência" (O ESTADO DE S. PAULO apud BARROS, 1960: 23). Como resultado os alunos foram dispensados de assistir as aulas para obterem os certificados. Dessa época vieram os "bacharéis e médicos elétricos", sem qualquer preparo que justificasse o título recebido. Em 1911, a reforma Rivadávia Correia instituiu a catástrofe da "liberdade sem controle e a ampla autonomia dos institutos oficiais" (Idem: 23-24).

Essas "excelentes notas" - conforme Fernando de Azevedo tratou o conteúdo editorial d O Estado de S. Paulo - auxiliaram a redação do Manifesto dos educadores. Concluía-se a partir delas que a terceira experiência de liberdade de ensino representava um risco iminente, devido ao inegável fracasso das tentativas anteriores. Além do mais, não haveria como seguir nesse caminho a partir do que ficou decidido constitucionalmente:

Supondo, pois, gravitar para a liberdade, os projetos que querem instaurá-la sem limitações, gravitam mas é para a desordem e a anarquia na educação. Pretendendo subtrair ao Estado os deveres que a Constituição lhe atribuiu, e que alcançam é largar o ensino a toda espécie de influências de grupos de pressão, divergentes e contraditórias. Mas a verdade é que entre as três posições que se podem tomar em face do problema, - a do monopólio do Estado, a de liberdade total e a de liberdade disciplinada, não nos resta mais o direito de escolha: a Constituição Federal já a adotou, em termos positivos. $\mathrm{O}$ documento a que aludimos, inverte totalmente esses termos; o que é principal (ensino público) na Carta Constitucional, passa a ser, nele, supletivo, e o que supre, completa ou substitui, isto é, a iniciativa privada, toma o lugar às funções ou ao papel que ao Estado atribuiu (MANIFESTO, 2003 [1959]: 166167). 
O redator do manifesto alertava que a "liberdade disciplinada" foi a tese vencedora da Constituição de 1946. Os projetos de diretrizes e bases teriam que observá-la para não serem arguidos de inconstitucionalidade. A fim de esclarecer ainda mais o que dizia, o professor Fernando de Azevedo recorreu à autoridade do parecer dado pelo jurista Jayme Junqueira Alves sobre a questão:

Senão vejamos os dispositivos constitucionais e demos a palavra a quem tem autoridade para proferi-la, quando se trata de questão de direito, - a um jurista, seja, por exemplo, o dr. Jayme Junqueira Ayres que os aponta com admirável lucidez em parecer sobre a matéria. "Um dos princípios firmemente assentes na Constituição Brasileira é o de que "o ensino dos diferentes ramos será ministrado pelos poderes públicos, e é livre a iniciativa particular, respeitadas as leis que o regulem (Art. 167)". Não caberá aqui (pondera o ilustre jurista) relembrar que este princípio é uma conquista da idade moderna e contemporânea: "corre ao poder público o dever de ministrar a educação popular. O que sobretudo cumpre e importa é observá-lo mais do que louválo. E cumpre, por igual, observar o da liberdade à iniciativa particular, de ministrá-la, respeitadas as leis respectivas (MANIFESTO, 2003 [1959]: 167).

Junqueira Alves considerava radical a doutrina exposta no substitutivo de Carlos Lacerda. Esse radicalismo o afastaria da constitucionalidade, praticamente demitindo o Estado das suas funções em relação à educação popular. Para o especialista em Direito Constitucional, Lacerda queria restringir não apenas o dever do Estado perante a educação, mas, até mesmo, o seu direito de fundar e manter escolas. A função supletiva do Estado, conforme determinado na proposta encaminhada à $\mathrm{CECCD}$, em janeiro de 1959, seria uma vertente heterodoxa entre as correntes do pensamento jurídico: "em franca rebelião contra o espírito e a letra expressa da Constituição" (PARECER, 1959: 152.

O Manifesto de 1959 era favorável, antes de mais nada, à defesa da ordem jurídica que abrigaria com maior facilidade os conceitos da renovação pedagógica. Na mensagem encaminhada ao povo e ao governo, Fernando de Azevedo afirmou que, tendo decorrido mais de vinte e cinco anos da primeira manifestação do grupo de educadores do qual fazia parte, o texto de Mais uma vez convocados era "menos doutrinário, mais realista e positivo" (MANIFESTO, 2003 [1959]:158). Esse posicionamento pode explicar o apoio de um órgão da imprensa liberal a uma causa pela qual lutavam também alguns jovens 
intelectuais radicais da USP, pesquisadores do INEP e do Instituto Superior de Estudos Brasileiros (ISEB), muitos deles com a fama de estarem próximos ao Partido Comunista.

\section{Entre a convicção e a responsabilidade intelectual}

Recolocar a verdade perante o público requer convicção. Os participantes de Mais uma vez convocados compartilharam com o seu redator a certeza de que lutavam pela causa certa. A acusação de Lacerda contra o monopólio estatal do ensino precisava de uma resposta à altura. Afinal, depois de anos dedicados a formar uma tradição políticopedagógica - a dos pioneiros da educação nova - vê-la derrotada por uma mentira seria um bom motivo para resistir. Eis o que Fernando de Azevedo escreveu:

Essa nova investida que irrompeu contra a interferência do Estado em matéria de ensino, e com ares de reação contra um suposto monopólio, parece ignorar que a educação pública - grande conquista da democracia do século XIX, já adquiriu prestígio e solidez em todos os países, e entre nós mesmos com mais de um século de tradição, que, se for desmantelada, será para ressurgir mais cedo ou mais tarde, com maior força de expansão (MANIFESTO, 2003 [1959]: 169).

O trecho em destaque expôs aquilo que poderia representar uma "ética da convicção" (WEBER, 1979 (1919): 144, passim). A capacidade de ressurgimento da educação pública como opção mais adequada para equilibrar igualdade e liberdade, frente a todos os abalos possíveis, faria com que os manifestantes de 1959 a vissem na forma de patrimônio pertencente ao campo das propostas político-pedagógicas da "era tecnológica". A mudança provocada pelas políticas de reconstrução educacional permitiria superar os entraves da mentalidade tradicional, preparando os jovens para um tipo de vida em constante transformação. A conquista da autonomia individual e a integração de classes na escola seriam indispensáveis ao aprimoramento da ordem competitiva.

Os intelectuais da educação, porém, não eram ideólogos stricto sensu, eram especialistas que vinham lutando por formas de profissionalização envolvendo cargos públicos e carreiras no magistério. A par disso, devemos acrescentar à "ética da convicção" os dilemas da "ética da responsabilidade" (WEBER, 1979 (1919): 144). 
Personagens do capítulo desenvolvimentista da história contemporânea do Brasil, os educadores da renovação pedagógica, como cientistas sociais, procuraram delinear o papel objetivo da educação enquanto artefato do progresso. Nesse quadro, a educação pública não representaria apenas uma "realidade moral" - como pensavam os que defendiam, antes de tudo, o direito das famílias - devendo estar comprometida com o progresso técnico e científico da nação. É o que exprime o trecho abaixo:

A revolução industrial, de base científica e tecnológica, que se expande por toda a parte, em graus variados de intensidade; as reinvindicações econômicas ou a ascensão progressiva das massas e a luta para melhorar suas condições de vida (pois a riqueza está evidentemente mal distribuída e, com tantas vezes já se lembrou, "não devemos pensar que podemos impunemente continuar a enriquecer enquanto o resto da população empobrece"); e, finalmente, a expansão do nacionalismo pelo mundo inteiro, são fatos sumamente importantes a que não nos arriscamos a fechar os olhos, e cujas repercussões, no plano educacional, vão se tornando cada vez mais largas e profundas. $\mathrm{O}$ nosso aparelhamento educacional terá também de submeter-se a essas influências para ajustar-se às novas condições, e só o Estado, pela amplitude de seus recursos e pela largueza de seu âmbito de ação, poderá fazer frente a tais problemas e dar-lhes soluções adequadas, instituindo, mantendo e ampliando cada vez mais o sistema de ensino público e estimulando, por todos os meios, as inciativas das entidades particulares (MANIFESTO, 2003 [1959]: 171).

Na situação de atraso do país, o meio mais adequado para atender as demandas educacionais do desenvolvimento econômico seria a escola pública-estatal. Apesar de reconhecerem as falhas dos mais variados governos na organização do ensino, os participantes do manifesto entendiam que a inversão proposta nos substitutivos de Carlos Lacerda representava um profundo revés no sentido da modernidade. O papel dos intelectuais seria de oposição "a todas as medidas radicais que, sob as aparências enganadoras de liberdade, tendem forçosamente a conduzir-nos ao caminho perigoso da anarquia senão das pressões ideológicas, abertas ou dissimuladas” (MANIFESTO, 2003 [1959]: 173).

A responsabilidade dos educadores liberal-democráticos estaria em resguardar os delineamentos legislativos que garantissem a existência de um sistema nacional de 
ensino, regulado pelo Estado, na ordem constitucional de setembro de 1946. Essa proposição não seria estranha ao mais importante órgão da imprensa liberal paulista, detentor de um projeto de formação da consciência nacional a se realizar verticalmente, das elites para as massas (CAPELATO, 1989: 150). As representações do intelectual em Mais uma vez convocados ecoaram na área afim ao jornal de Júlio de Mesquita Filho, em um tempo em que os liberais ainda acreditavam em reformas dentro da legalidade.

\section{Fontes}

A AEC CONDENA a resolução precipitada e injusta da COFAP (1958). Servir: Boletim da AEC do Brasil. Rio de Janeiro, vol. 11, pp. 19-23, abril.

ATA da $13^{\circ}$ reunião ordinária da Comissão de Educação e Cultura da Câmara dos Deputados (1958). Diário do Congresso Nacional, 26 nov. Disponível em http://imagem.camara.gov.br/dc_20b.asp. Acesso em 15 jan. 2010.

PARECER de Jayme Junqueira Alves sobre inconstitucionalidade do substitutivo do deputado Carlos Lacerda ao projeto ${ }^{\circ}$ 2.222-B/1957, que fixa as diretrizes e bases da educação nacional (1959). Revista Brasileira de Estudos Pedagógicos, vol. 31, n. 74, pp. 150-157, abr./jun.

\section{Referências Bibliográficas}

ARENDT, Hannah (1988). Entre o passado e o futuro. Trad. Rosaura Eichenerg. 2 ed. São Paulo: Perspectiva.

BARROS, Roque Spencer (Org.) (1960). Diretrizes e bases da educação. São Paulo: Pioneira.

BAUMAN, Zygmunt (2010). Legisladores e intérpretes. Sobre modernidade, pósmodernidade e intelectuais. Trad. Renato Aguiar. Rio de Janeiro: Zahar.

BOBBIO, Norberto (1997). Os intelectuais e o poder. Dúvidas e opções dos homens de cultura na sociedade contemporânea. Trad. Marco Aurélio Nogueira. São Paulo: Unesp.

BOMENY, Helena (2001). Darcy Ribeiro. Sociologia de um indisciplinado. Belo Horizonte. UFMG.

BONTEMPI Jr., Bruno (2001). A Cadeira de História e Filosofia da Educação da USP entre os anos 40 e 60: um estudo das relações entre vida acadêmica e grande imprensa. Tese (Doutorado em Educação). Universidade de São Paulo, São Paulo.

CAPELATO, Maria Helena (1989). Os arautos do liberalismo: imprensa paulista (19201945). São Paulo: Brasiliense.

CARDOSO, Irene (1982). A universidade da comunhão paulista. São Paulo: Cortez.

CARVALHO, João do Prado Ferraz de (2003). A campanha de defesa da escola pública em São Paulo (1960-1961). Tese (Doutorado em Educação) Pontifícia Universidade Católica de São Paulo, São Paulo.

LIMONGI, Fernando P (1988). Educadores e empresários culturais na construção da USP. Dissertação (Mestrado em Ciência Política). Universidade Estadual de Campinas, Campinas, SP. 
MAGALDI, Ana Maria \& GONDRA, José Gonçalves (Orgs.) (2003). A reorganização do campo educacional no Brasil. Manifestos, manifestações e manifestantes. Rio de Janeiro: 7 Letras.

MANIFESTO dos Educadores: mais uma vez convocados (2003 [1959]). In: MAGALDI, Ana Maria \& GONDRA, José Gonçalves (Orgs.). A reorganização do campo educacional no Brasil. Manifestos, manifestações e manifestantes. Rio de Janeiro: 7 Letras, pp. 157-177.

MONTAlVÃO, Sérgio (2011). Por uma História Política da Educação: a Lei de Diretrizes e Bases e a democracia da Terceira República (1946-1961). Tese (Doutorado em História, Política e Bens Culturais). Fundação Getúlio Vargas, Rio de Janeiro.

MONTALVÃO, Sérgio (2013). Liberdade de ensino versus totalitarismo: a semântica política dos substitutivos de Carlos Lacerda durante a tramitação da Lei de Diretrizes e Bases (1958-1959). Revista de História (USP). São Paulo, vol. 169, pp. 293-322.

MONTEIRO, Norma (Org.) (2007). O Brasil de Clóvis Salgado. Belo Horizonte: Museu Histórico Abílio Barreto.

RODRIGUES, Helenice (2005). O intelectual no "campo" cultural francês: do "Caso Dreyfus" aos dias atuais. Varia História. Belo Horizonte, vol. 21, n. 34, pp. 395413, jul. Disponível em: 〈http://www.scielo.br/pdf/vh/v21n34/a08.pdf>. Acesso em: 10 ago. 2015.

SAID, Edward (2005). Representações do intelectual. Trad. Milton Hatoum. São Paulo: Companhia das Letras.

SENRA, Álvaro de Oliveira (2011). Ação política católica e educação escolar. Curitiba, CRV.

SIRINELLI, Jean-François (1996). Os intelectuais. In. REMOND, René. Por uma história política. Trad. Dora Rocha. Rio de Janeiro: Ed. FGV/Ed. UFRJ, pp. 231270.

TEIXEIRA, Anísio (2005) [1957]. A educação que nos convém, In. Educação não é privilégio. Rio de Janeiro, UFRJ.

WEBER, Max (1979) [1919]. A política como vocação. In. GERTH, Hans H. \& MILLS, Charles. W. (Orgs.) Ensaios de sociologia. Trad. Waltensir Dutra. 4 ed. Rio de Janeiro: Zahar, pp. 97-153.

Artigo recebido em 5 de setembro de 2015.

Aprovado em 15 de novembro de 2015.

DOI: $10.12957 /$ intellectus.2015.20987 